\title{
Oil palm: a sustainable agro-industry in Colombia
}

\author{
Pedro L. GÓMEZ \\ Mauricio MOSQUERA \\ Carlos CASTILLA \\ Cenipalma \\ Calle 21 \\ No. 42 c 47 \\ Bogotá \\ Colombia \\ <dir.ejecutiva@cenipalma.org>
}

Colombia's rural sector has the potential to mitigate poverty and contribute to the economic development process. For this, its contribution must consider environmental, social and economic variables. Environmentally, the conception of agriculture as a depredatory activity is now behind given way to an agriculture that takes into account the needs of future generations. Socially, we view rural populations in terms of political stability, and the need to redistribute resources as a starting point for a process of balanced development. Economically, the agricultural sector increasingly contributes to the integration of agricultural activity with the other sectors of the economy, going beyond the net production of raw materials.

Incorporating these elements, the cultivation of oil palm in Colombia has evolved to become one of the main government strategies for generating rural employment and income. From the perspective of its progress and achievements, this document describes the sustainability of the Colombian oil palm culture in these three important areas: economic, social and environmental.

\section{Context}

The cultivation of oil palm has developed most intensely in Malaysia and Indonesia, who share about $80 \%$ of the entire oil palm production area in the world. At the secondary level, by order of importance, are Nigeria, Thailand, Colombia and Ivory Coast. Together, these countries account for about $12 \%$ of the world's palm producing area.

By 2003, South America harvested about four hundred thousand hectares of oil palm, $40 \%$ of them in Colombia producing slightly more than $50 \%$ of the region's fruit, due to its higher volume of production per area unit (table 1).

\section{Colombia: regional distribution of cultivated area}

It is estimated that in 2004 Colombia reached a total of 243,000 hectares planted to oil palm. However 80,000 of which are still in the development stage and unproductive [1]. Compared to other oil palm producing countries, Colombia has four contrasting oil palm producing zones: 1) the Western Zone: at the south of western Colombia, on the Pacific coast; 2) the Northern Zone: in the northeastern part of the country, near the Atlantic coast; 3 ) the Central Zone: an inter-Andean valley of the Magdalena River system; and 4) the Eastern Zone: at the foothills of the Eastern chain of the Andes range (figure 1).

In 2004, the Eastern Zone concentrated the largest area planted in oil palm, at $31.4 \%$, followed by the Northern Zone at $31 \%$, the Central Zone with $25.2 \%$ and finally the Western Zone with $12.5 \%$. Yet, the potential area for production of oil palms in Colombia, without mayor agronomic restrictions, is more than 3.2 million hectares. These areas are located mainly in the Eastern Zone (59\%), in the Central Zone $(21 \%)$ and the Northern Zone (18\%) [2]. In other words, the country has the potential to significantly increase the oil palm growing area.

\section{Sector production and GDP}

The main agro-industrial palm products are crude palm oil, crude palm kernel oil, and palm kernel cake. Between 1960 and 2003 production increased rapidly, with palm oil production growing at an annual rate of $13.5 \%$, crude palm kernel oil at $11.76 \%$ yearly, and palm kernel cake increasing by $11.82 \%$ yearly (table 2).

The net value of oil palm production is approximately 300 million dollars per year. For the past five years, the sector's participation in the Gross Domestic Product (GDP) has averaged 6.74\% of the total value of permanent crops, $3.52 \%$ of agricultural sector value, and $2.0 \%$ of the value produced by the entire Colombian farming sector.

\section{Exports and market destination}

The portion of Colombian crude palm oil and palm kernel oil dedicated to export has been increasing since 1994 , when it stood at $6 \%$. By 2004 , around $40 \%$ of the sector's production was exported (table 3).

Table 1. Statistics on Oil Palm Production in South America (Year 2003).

\begin{tabular}{|lcccc|}
\hline Country/Region & $\begin{array}{c}\text { Harvested Area } \\
(\mathbf{H a})\end{array}$ & $\begin{array}{c}\text { Production } \\
(\mathbf{M t})\end{array}$ & $\begin{array}{c}\text { Yield } \\
\text { Ton/Ha }\end{array}$ & $\begin{array}{c}\text { Oil Production } \\
\text { (Ton) }\end{array}$ \\
\hline South America & 377,449 & $5,220,796$ & 14 & $1,043,939$ \\
Colombia & 150,399 & $2,579,459$ & 18 & 526,634 \\
Ecuador & 125 & $1,450,000$ & 12 & 290 \\
Brazil & 51,6 & 516 & 10 & 103,2 \\
Venezuela & 25,1 & 313,75 & 13 & 62,75 \\
Paraguay & 13,3 & 180,446 & 10 & 36,089 \\
Peru & 11,5 & 126,5 & 16 & 25,3 \\
\hline
\end{tabular}

Source: FAO. 


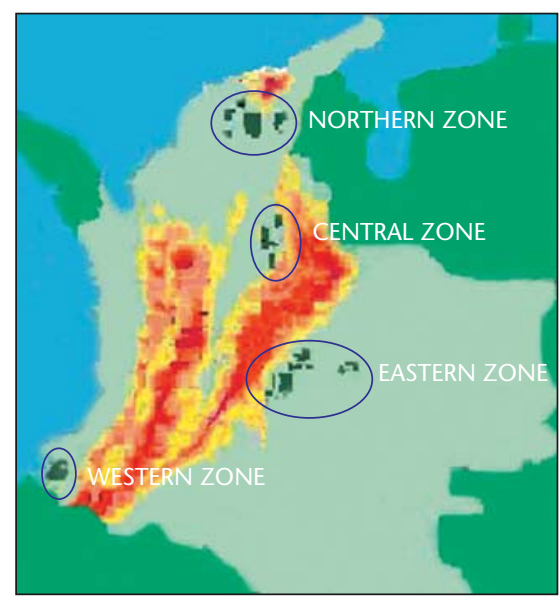

Figure 1. Colombia oil palm cultivated zones.

\section{Uses of oil palm agro-industrial products in Colombia}

The products of the agro industry area used in industrial processes dedicated to four types of goods: direct human consumption, animal feeds, manufacture of non edible products and oleo chemicals.

Both, the liquid (oleic) and solid (stearin) portions of crude palm and palm-kernel oils are for human consumption as cooking oils, margarines, industrial fats, candies, pastries, emulsifiers, and other products, and account for $56 \%$ of the oils and fats produced in Colombia.

The crude palm oil and the palm kernel cake are used in the preparation of animal feed. The non-food products which incorporate oil palm byproducts are soaps, fuels, candles, cosmetics and inks. Finally, oil palm agro-industrial products also appear in the oleo-chemical industry as epoxidized oils, polyurethane foam, polyhydric alcohols, polyacrylic resins, fatty acids, non-sodic soaps and fatty esters.

\section{The social importance of Colombian oil palm culture}

During the last fifteen years Colombia has experienced the effects of liberalized trade

Table 2. Colombia: Production of agro-industrial Palm sub-products. 1961-2003.

\begin{tabular}{|lccc|}
\hline Production (Ton) & Palm oil & Palm kernel cake & Palm kernel oil \\
\hline 1961 & 1,7 & 275 & 225 \\
1965 & 2,2 & 495 & 405 \\
1970 & 26,9 & 3,85 & 3,15 \\
1975 & 39,2 & 5,225 & 4,275 \\
1980 & 69,8 & 9,35 & 7,65 \\
1985 & 125,25 & 13,372 & 10,941 \\
1990 & 251,961 & 25,451 & 20,824 \\
1995 & 387,646 & 35,93 & 28,744 \\
2000 & 524,001 & 56,207 & 45,432 \\
2001 & 547,571 & 61,159 & 49,781 \\
2002 & 528,4 & 59,853 & 48,717 \\
2003 & 526,634 & 65,443 & 49,766 \\
\hline
\end{tabular}

Source: FAO-Fedepalma.

Table 3. Destinations of crude palm oil and crude palm kernel oil.

\begin{tabular}{|lcc|}
\hline Country & Palm oil & Palm kernel oil \\
\hline England & 40,6 & 23,5 \\
Peru & 14 & 9,8 \\
Venezuela & 10,5 & 10,1 \\
Brazil & 8,3 & 2,4 \\
Mexico & 4 & 42,7 \\
Chile & 3,5 & 4,2 \\
Dominican Rep. & 3,4 & \\
Netherlands & 2,3 & \\
Panama & 2,2 & \\
United States & 2,1 & \\
Germany & 2 & 7,2 \\
Others & 7 & 100 \\
Total & 100 & \\
\hline
\end{tabular}

Source: Fedepalma. agreements (commercial aperture) without a strategy to consolidate the agricultural sector's ability to handle it. As a result, the competitive skills of all Colombian rural sector actors were not properly developed. There are instances where for some sectors the adaptation has not been traumatic and may have even benefited. At the other extreme, however, other sectors are facing immense obstacles to continuing their productive activities, because they are forced to compete with more efficient and subsidized producers in other countries [3], and have generated a runaway increase in rural poverty rates.

Given the lack of opportunities, the bankruptcy of many legal business, and limited state assistance by the Colombian government, the rural labor force has been forced to participate in the cultivation of illegal crops. Yet, this income source is not a viable alternative since it destroys the social fabric and disrupsts the moral values and customs of the Colombian society [4].

It is in this context were the sustained growth of products like the oil palm has proved to be quite positive, since it functions as a valid alternative that offers good living conditions for the personnel involved. Permanent crops thus have comparative advantages because of their adaptation to the natural environment, and furthermore offer better conditions to the rural worker as he or she enters into more complex production processes with greater added value.

In Colombia, the oil palm is backed by a solid, business-oriented sectoral production organization (Fedepalma - Colombian Federation of oil palm growers) that has been able to design adequate strategies for positioning its products into the macro-economic environment. These include the generation of social capital in the oil palm-growing regions.

The palm-oil companies have invested in the provision of social services (health and education) for the local communities that provide labor, supported the organization of cooperatives for rural workers to provide labor for the palm companies [5], and stimulated the development of productive partnerships. These productive partnerships establish integration agreements among the different social elements of the Colombian rural areas (farmers, businessmen and government). In such arrangements, farm workers provide manpower, knowledge, and resources; and the State guarantees investment incentives such as low interest rates, grace periods for credit payments, and other economic incentives. For their part, companies commit themselves to buy the fruit production, and to provide technical assistance. In some cases they provide knowledge of the production and marketing processes, 
acting as managers of the productive partnerships [6].

As a result of these initiatives, it may be observed that rural workers involved in the oil palm have higher incomes than the rest of the population, and that the oil palm-producing communities have a more equitable income distribution than the rest of the Colombian rural population [5].

Notably, nationwide the agro-industry generates around 27,000 direct jobs, and an estimated 25,000 indirect ones [7]. In addition, the oil palm plantations are situated in areas of very low demographic density, averaging one inhabitant for every 3.7 hectares, generating around one direct job for every 7 hectares.

The results of a survey taken in the oil palmproducing municipalities of Colombia indicate that: 1) oil palm workers' homes enjoy greater economic stability than those of workers in other rural activities; 2) oil palm culture is seen as an activity that generates well-remunerated employment for relatively unskilled labor; and 3) oil palm production is perceived as a barrier to the expansion of illegal crops [5].

\section{Oil palms and the environment}

One of the sector's main concerns has been the sustainable management of the plantations. The results of a recent study have been published in the book entitled Environmental performance of the Colombian palm culture sector [8], show the following findings.

The impact of the world wide level cultivation of oil palms on biodiversity has been the theme of intense debate, because of the destruction of tropical forest areas in Malaysia and Indonesia. However, the situation in Colombia has been different, because even though a high proportion of the area was originally forested, $87 \%$ of the areas planted to oil palm were previously used for annual crops and extensive cattle grazing with some degree of degradation. In such cases oil palm contributes significantly to ecosystems improvement (because its perennial nature allows for natural resilience to restore degraded soil resources and its high carbon sequestration potential contributes to minimize the overall effects of green house gases). In addition, the nature of the cropping system is such that allows for the adaptation and/or generation of management strategies and actions coherent with a sustainable management of the crop. Examples of these are:

- Pest and diseases control: as an alternative to the vulnerability of monocropping systems to attacks by pests and diseases, strategies to enhance the strengthening of the ecosystems include one or more of the following: 1) planting leguminous plants to protect the soil and minimize weed growth, 2) planting nectariferous species which host natural pest predators, 3) replacing applications of broad-spectrum pesticides with specific biocides, and 4) increasing the tolerance to pests and disease attacks by adequate fertilization programs.

- Incorporation of organic matter: most plantations use as a soil management practices the incorporation of mill byproducts (empty fruit bunches, shells and fiber). Though neglected in the past, palm oil mill effluents are now increasingly used as fertilizer.

- Sustainable water management: in association with banana growers, the oil palm-growing sector is leading programs to recover, protect and manage fifteen river-basins in the Sierra Nevada de Santa Marta (northern Colombia). - Handling of effluents: at the beginning of the decade of the nineties, the main environmental impact of this agro-industry on the environment was the dumping of extraction process byproducts into bodies of water. Today, $99 \%$ of the extracting plants have effluent treatment systems. Furthermore, they are following the country's environmental norms concerning the permitted organic load of discharged water.

- Gas emissions: Some companies use the methane gas generated in their effluent treatment ponds as a source of energy for their extracting mill. With this practice, in addition to reducing costs, they avoid the release of a gas that contributes to the deterioration of the ozone layer.

Finally, the sector's commitment to environmental management is evidenced by the fact that each company operating in the sector must have an environmental management plan of action which is implemented and functional.

\section{Science and technology for palm agro-industry}

In Colombia, sectoral associations have gained strength by establishing contracts with the State to manage public resources deriving from the taxes paid by its associates. In the case of the oil palm, Fedepalma collects a fee amounting to $1 \%$ of the value of the crude palm oil and $1 \%$ of the value of the palm kernel, which is used for investment in the development of the palm oil sector in the areas of a) research, technical assistance and technology transfer; b) sanitary control, c) commercialization, d) promotion of product consumption, and e) economic, social and infrastructure programmes [9].

One of the Colombian oil palm-growing sector's strategies has been to invest in technology. This interest led to the creation, in 1991, of the Oil Palm Research Center (Cenipalma), which uses these resources and others from national and international financial agencies to finance its research agenda.

\section{Problems}

Most pests and diseases of oil palm in Colombia are unknown in other places, so it cannot be expected that technology developed in other countries be adapted. Instead, Colombia must develop its own technology. Furthermore, the regional diversity of Colombia's oil palm production zones is manifested in varying climatic conditions and diverse soil characteristics, which is reflected in specific problems for each region (table 4).

The most significant problems associated with oil palm culture in Colombia are: 1) Northern Zone: water deficit, 2) Central Zone: water deficit, pests, poor soils and aluminum saturation, 3) Eastern Zone: water deficit, diseases, aluminum saturation, and poorly drained and compacted soils, and 4) Western Zone: diseases and pests.

\section{Research strategies}

1) Cenipalma develops and performs its research agenda according to the mandate of the oil palm growers, represented by research advisory committees that they themselves elect. Every zone has thematic committees in agronomic practices, mill management, and a third one that brings together owners and managers. They prioritize regional research activities, which are then ratified by nationallevel committees on each theme and submitted for consideration by Cenipalma's maximum policy-forming body, the General Assembly. Research projects are locally reviewed at seminars held twice a year in each Zone.

2) Cenipalma performs a large part of its research on commercial plantations. There, the companies' technicians, together with those from Cenipalma, supervise and control the quality of the experiments and their results. In this way the applicability of the resulting technologies is ensured, personnel from the plantations are trained, and resources to support the research are leveraged from the companies. Cenipalma also hires external advisors of the highest level to provide technical supervision of its research work.

The participation of students in research projects at Cenipalma should be mentioned as a contribution to the development of human resources. According to estimates by Cenipalma's Office of Human Resources, around $70 \%$ of the technical personnel currently working in the Colombian oil palm culture sector have had some kind of work association with Cenipalma. 
Table 4. Soil and climate characteristics of Colombia's palm-oil producing regions [10].

\begin{tabular}{|c|c|c|c|c|}
\hline Characteristic & Western zone & Northern zone & Central zone & Eastern zone \\
\hline \multicolumn{5}{|l|}{ Climate } \\
\hline Average temperature & $28^{\circ} \mathrm{C}$ & $27^{\circ} \mathrm{C}$ & $26^{\circ} \mathrm{C}$ & $26^{\circ} \mathrm{C}$ \\
\hline Annual precipitation & $2000-3000 \mathrm{~mm}$ & $1000-2000 \mathrm{~mm}$ & $2000-4000 \mathrm{~mm}$ & $2000-4000 \mathrm{~mm}$ \\
\hline Solar radiation & 2,158 hours & 1,540 hours & 1,607 hours & 2,479 hours \\
\hline Relative humidity & $81.3 \%$ & $81.6 \%$ & $77.2 \%$ & $79.8 \%$ \\
\hline \multicolumn{5}{|l|}{ Soils } \\
\hline \multirow[t]{6}{*}{ Classification } & Tropepts & Fluvents & Oxic Dystropept & Aquic Tropofluvent \\
\hline & Fluvents & Orthents & Typic Tropaquept & Oxic Dystropept \\
\hline & Histosoles & Tropepts & Aeric Tropaquept & Aquic Dystropept \\
\hline & & & Typic Dystropept & Typic Tropaquept \\
\hline & & & Fluventic Dystropept & Aquoxic Dystropept \\
\hline & & & & Aquic Paludos \\
\hline Other characteristics & Moderately Evolved & Moderate fertility & Low to moderate fertility & Evolved \\
\hline
\end{tabular}

3) Cenipalma recently inaugurated its own research station located in the Central Zone the first to be established for the oil palm sector. Its mission is to perform research in areas that would be difficult to implement on commercial plantations, such as the development of varieties, processes that include destructive testing of palms, evaluation of planting densities, and maintenance of the germplasm bank.

\section{Lines of research}

Cenipalma currently has fourteen macroprojects, in five research areas: 1) plant health; 2) soil and water management; 3) production of improved varieties, 4) processes and uses; and 5) economy and biostatistics.

\section{Impact}

The impact of investing in research has been evident over the past fifteen years. Indeed, the per-hectare oil yield has gone from 2.5 to 4 tons, while oil losses have dropped by $20 \%$ (from $2.1 \%$ to $1.7 \%$ per ton of fresh fruit bunches). A study by CEGA (Cattle and agricultural studies center) on the impact of Cenipalma's work showed that, in the most pessimistic scenario, for every Colombian peso invested in research, there has been a yield of four pesos for the palm sector, while the most optimistic scenario places this yield at sixteen pesos [11].

\section{Conclusion}

This article has reviewed the performance of the Colombian oil palm sector from the social, economic and environmental perspective. It has shown an agro-industry with a capacity to face a complex situation in the rural areas of Colombia, where poverty coexists with illicit crops. Oil palms offer a viable alternative in which the palm worker's quality of life is high (in terms of job stability, health services and education).

On the other hand, the sector's concern to avoid negative impacts on the ecosystem, and its investment in research, has already produced results. Today, in addition to being friendlier to the environment, palm agro-industry is more productive.

The challenges are still great. Colombia's government has signed free trade agreements with countries that produce palm oil substitutes while the area of oil palm cultivation is increasing along with the concomitant problems. Furthermore, country's internal demand for palm oil products now is satisfied, and there is a need to reduce costs in order to compete on the international market. However, the oil palm-growing sector is confident that it will be able to continue to overcome obstacles and consolidate itself as a sustainable agro-industry in Colombia.

\section{REFERENCES}

1. FEDEPALMA. Anuario estadístico. Bogotá: Fedepalma, 2004.

2. ROMERO M, MORENO A, MUNEVAR F. Evaluación edafoclimática de las tierras del trópico bajo colombiano para el cultivo de la palma de aceite. Bogotá: Cenipalma-Corpoica. 1999: 1-30.
3. BALCÁZAR A, VARGAS A, OROZCO M. Del proteccionismo a la apertura. Misión Rural. Bogotá: Editorial Tercer Mundo. 1998: 1-131.

4. MOSQUERA M. Exclusión y coerción: cultivos ilícitos y Plan Colombia. In: Economía Colombiana y Coyuntura Política. Bogotá: CGR. 2001; 284: 85-9.

5. PERFETTI M. Impactos socioeconómicos de la agroindustria de la palma de aceite en Colombia. Bogotá: Fedepalma. 2004: 1-82

6. MINISTERIO DE AGRICULTURA Y DESARROLLO RURAL. Alianzas Productivas para la Paz. Bogotá: Minagricultura. 1999: 1-15.

7. FEDEPALMA. Censo nacional de palma de aceite. Colombia 1997-1998. Bogotá: Fedepalma. 1999: 260.

8. RODRÍGUEZ M, VAN HOOF B. Desempeño ambiental del sector palmero en Colombia. Bogotá: Fedepalma. 2004: 157.

9. fedepalma. Fondo de Fomento Palmero. Bogotá: Fedepalma. 1994: 1-24.

10. MUNÉVAR. Problemática de los suelos cultivados con palma de aceite en Colombia. In: Memorias XII Conferencia Internacional sobre Palma de Aceite. 1997: 1: 218-28.

11. BALCÁZAR A, OROZCO M, ROLDAN D, ROMERO, J, TRIANA, J. Evaluación costobeneficio del cambio tecnológico en la agroindustria de la palma de aceite. Bogotá: CECA. 2000: 1-109. 